\title{
Druki ulotne i okolicznościowe Zakładów Graficznych Instytutu Wydawniczego „Biblioteka Polska" w zbiorach Wojewódzkiej i Miejskiej Biblioteki Publicznej w Bydgoszczy. Przyczynek do dziejów wydawnictwa
}

\begin{abstract}
Streszczenie. W Bydgoszczy w latach 1920-1939 działały Zakłady Graficzne Instytutu Wydawniczego „Biblioteka Polska”. Zostały one założone przez wielkopolskiego ziemianina Władysława Kościelskiego. Należały do największych i najnowocześniejszych w dwudziestoleciu międzywojennym w Polsce. Instytut Wydawniczy „Biblioteka Polska”, z siedzibą w Warszawie, w seriach wydawniczych ogłosił kilkaset tytułów dzieł autorów polskich oraz zagranicznych. Opublikował również liczne druki ulotne i okolicznościowe. Kierowane do szerokiego kręgu odbiorców pozycje cechowała komunikatywność, jak również czytelność. Pełniły one przede wszystkim funkcję informacyjno-reklamową. Wprowadzone do obiegu czytelniczego wykazują zróżnicowanie pod względem treści i formy typograficznej (ze względu na charakter zdobnictwa, układ graficzny czy dobór czcionki). Odegrały ważną rolę w kształtowaniu świadomego odbiorcy książki i prasy, miały wpływ na kształtowanie potrzeb czytelniczych, upowszechnianie dorobku pisarzy oraz uczonych. Były projektowane przez uznanych grafików, a także ilustratorów książki. Stanowią cenny materiał źródłowy o charakterze dokumentacyjnym, historycznym i estetycznym.
\end{abstract}

SŁowA KLUCzowe: Instytut Wydawniczy „Biblioteka Polska” (Warszawa), Zakłady Graficzne Instytutu Wydawniczego „Biblioteka Polska” (Bydgoszcz), Władysław Kościelski, druki ulotne, drukarstwo, edytorstwo, księgarstwo, Wojewódzka i Miejska Biblioteka Publiczna w Bydgoszczy, zbiory biblioteczne.

Jedną z wielu instytucji wydających druki ulotne i okolicznościowe w dwudziestoleciu międzywojennym w Polsce były bydgoskie Zakłady Graficzne Instytutu Wydawniczego „Biblioteka Polska”. Powstały one w 1920 roku za sprawą wielkopolskiego ziemianina Władysława 
Kościelskiego ${ }^{1}$, który tego samego roku powołał do życia spółkę akcyjną Instytut Wydawniczy „Biblioteka Polska”2. Głównym akcjonariuszem spółki był Władysław Kościelski, a współzałożycielami byli Leopold Staff, Wacław Berent i Leonard Bobiński. Pierwszym prezesem Rady Nadzorczej został Jan Kasprowicz, dyrektorem naczelnym Tadeusz Pini, dyrektorem działu literackiego Aleksander Guttry, prokurentem Aleksander Kołłupajło. Centrala wydawnictwa mieściła się w Warszawie, przy Krakowskim Przedmieściu (następnie przy ul. Świętojańskiej), natomiast jedyna drukarnia w Bydgoszczy, przy ul. Jagiellońskiej (il. 1). Zakłady Graficzne, określane mianem „instytucji bydgoskiej kultury"3, należały do największych i najnowocześniejszych w Polsce. W wyniku postępującej modernizacji wykonywały wszelkie druki w technikach druku płaskiego, rotograwiurze i offsecie jednobarwnym oraz wielobarwnym. Przed wybuchem II wojny światowej w 1939 roku zatrudniały ponad 600 osób $^{4}$.

Wydawnictwo Instytutu Wydawniczego „Biblioteka Polska” w sposób istotny przyczyniło się do wzrostu kultury czytelniczej w skali całego kraju ${ }^{5}$. Na podkreślenie zasługuje fakt, iż w seriach wydawniczych ogłosiło ponad 800 dzieł autorów polskich i zagranicznych ${ }^{6}$. Zbiorowe wydania objęły prace m.in.: Wacława Berenta, Juliana Kaden-Bandrowskiego, Jana Kasprowicza, Kornela Makuszyńskiego, Władysława Orkana, Stanisława Przybyszewskiego, Wacława Sieroszewskiego, Stanisława Wyspiańskiego, Stefana Żeromskiego. Prowadzono bogatą działalność wydawniczą w zakresie literatury pięknej, historii, historii literatury czy

${ }^{1}$ Władysław Kościelski (1886-1933), wydawca, poeta, tłumacz, mecenas sztuki. Z Ludwikiem Morstinem w latach 1911-1913 wydawał i redagował miesięcznik „Museion". Współzałożył w Monachium wydawnictwo przekładów literatury polskiej „Polnische Bibliothek”. W Bydgoszczy w 1919 roku zakupił za 6 milionów marek, spłaconych w okresie dewaluacji, niemiecką drukarnię z dużym zapasem papieru. Rok później przekształcił ją w Zakłady Graficzne Instytutu Wydawniczego „Biblioteka Polska".

2 Zob. A. Sucharska, Z dziejów Zakładów Graficznych „Biblioteki Polskiej”, w: Biblioteka Polska. Bydgoska oficyna wydawnicza w latach 1920-1939, Bydgoszcz 1983, s. 11-26.

3 Z. Mrozek, Polska kultura i sztuka w Bydgoszczy w latach 1920-1939, w: Historia Bydgoszczy, t. 2, cz. 1: 1920-1939, red. M. Biskup, Bydgoszcz 1999, s. 742.

4 A. Tujakowski, Z drukarskich tradycji Bydgoszczy, „Kronika Bydgoska” 1971, t. 2 (1964-1965), s. 84. W 1939 roku Niemcy zniszczyli zgromadzone zapasy wydawnictw i zajęli zakłady. Po wojnie „Biblioteka Polska” na krótko wznowiła działalność. Drukarnia została upaństwowiona.

${ }^{5}$ Zob. H. Dubowik, Działalność wydawnicza "Biblioteki Polskiej”, w: Biblioteka Polska. Bydgoska oficyna wydawnicza w latach 1920-1939, Bydgoszcz 1983, s. 29-53.

${ }^{6}$ Z. Mrozek, op.cit., s. 741. 


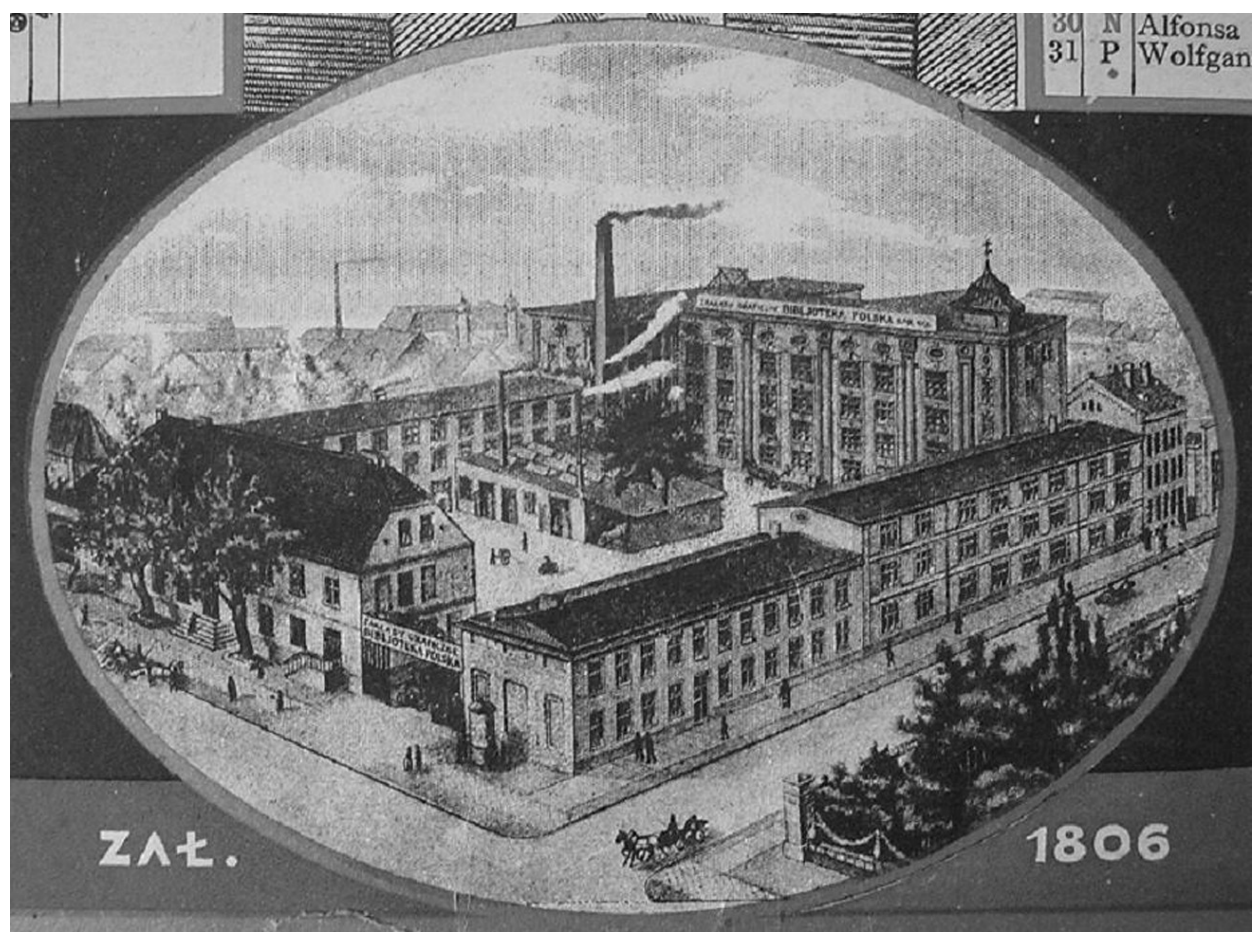

Il. 1. Widok Zakładów Graficznych Instytutu Wydawniczego „Biblioteka Polska” w Bydgoszczy (fragment kalendarza na rok 1932)

Źródło: Wojewódzka i Miejska Biblioteka Publiczna w Bydgoszczy, Zb. Specj. Dżs. XVI. 2 Biblioteka Polska; fot. Ryszard Nowicki.

językoznawstwa. Ogłaszano drukiem arcydzieła literatury polskiej i obcej (np. utwory George'a Byrona, Johanna Goethego, Jeana Moliera, Friedricha Schillera, Williama Szekspira), dbając jednocześnie o szatę edytorską oraz staranne przekłady. O wysokim prestiżu świadczy przyznanie w 1929 roku na Wystawie Powszechnej Krajowej w Poznaniu złotego medalu za całokształt działalności wydawniczej. Zakłady Graficzne publikowały dzieła rodzimych i zagranicznych mistrzów pióra, czasopisma („Nowy Przegląd Literatury i Sztuki”, „Przegląd Warszawski”, ,Polonista", "Życie Literackie”), podręczniki szkolne, albumy, a także liczne druki ulotne i okolicznościowe.

W podjętych badaniach wystąpiła podstawowa trudność związana z faktem, iż zbiór druków ulotnych i okolicznościowych Zakładów Graficznych Instytutu Wydawniczego „Biblioteka Polska” nie jest kompletny. Do obiegu masowego wprowadzano niejednokrotnie ich spore nakłady, zostały one jednak rozproszone bądź też nie przetrwały do naszych czasów. Nie sposób jest także podać ich ogólnej liczby. Być może 
nigdy nie będzie to możliwe. Należy pamiętać, że zakłady realizowały również zamówienia wielu instytucji, stowarzyszeń, firm czy osób prywatnych (m.in. Ministerstwa Komunikacji, Poczty Polskiej, Telegrafu i Telefonu, Polskich Linii Lotniczych Lot, biura turystycznego "Orbis", Zakładów Mechanicznych „Ursus”). Uwagę zatem skupiono na wycinkowym fragmencie tego rodzaju przekazów typograficznych wydanych w okresie międzywojennym przez Zakłady Graficzne, a zgromadzonych w Zbiorach Specjalnych Wojewódzkiej i Miejskiej Biblioteki Publicznej w Bydgoszczy ${ }^{7}$.

Istniały różne rodzaje druków ulotnych wychodzących spod pras bydgoskich zakładów, m.in.: afisze, banknoty (marki polskie), kalendarze, katalogi, plakaty, pocztówki ${ }^{8}$. Wśród nich szczególną wartość, związaną z kulturą książki, mają katalogi księgarskie i wydawnicze. Przykładowo w ogłoszonym w 1929 roku Katalogu celniejszych dzieł do nabycia w ksiegarni Gubrynowicza i Syna we Lwowie zawarte są liczne wiadomości, z których czytelnik dowiaduje się, jaki był asortyment księgarski oraz jakie pozycje publikował Instytut Wydawniczy „Biblioteka Polska” (il. 2). W tekście ujętym w ramkę oferowano niezwykle wartościowy album Dzieła malarskie Stanisława Wyspiańskiego. Książka, do której tekst napisali Stanisław Przybyszewski i Tadeusz Żuk-Skarszewski, została nagrodzona w 1928 roku przez Polskie Towarzystwo Wydawców Książek. Odnotowano format pracy, liczbę stron, rodzaj papieru, technikę wykonania ilustracji, rodzaj oferowanych opraw. Podkreślono walory edytorskie publikacji:

Dzieło to, wydane w nadzwyczaj wytwornej szacie, będące pod względem jakości reprodukcji ostatnim słowem techniki drukarskiej, jest bezsprzecznie najwspanialszym wydawnictwem z zakresu plastyki, jakie dotąd w Polsce ukazało się, i przedstawia $\mathrm{w}$ wyczerpujący sposób niezwykłą twórczość malarską Stanisława Wyspiańskiego. Dzieło to stanowi chlubę polskich wydawnictw artystycznych...

Na innej stronie zachęcano do nabycia Dzieł Stanisława Wyspiańskiego, w opracowaniu Adama Chmiela i Tadeusza Sinki, podkreślano, iż:

Pierwsze to nie tylko zbiorowe, lecz i krytyczne wydanie dzieł twórcy „WESELA", obejmuje całą jego spuściznę literacka, a więc oprócz dramatów

${ }^{7}$ Druki ulotne i okolicznościowe znajdują się w jednostce opatrzonej sygnaturą Zb. Specj. Dżs. XVI. 2 - Biblioteka Polska.

${ }^{8}$ Interesujący materiał źródłowy stanowią również dokumenty wydane w formie etykiet. 
i tragedii, fragmentów dramatycznych i przekładów liryki i rapsodów[,] także prozę i korespondencję.

W katalogu zasygnalizowano też książki, które były wydawane przez Instytut Wydawniczy w seriach. Rzucają one światło na realizowane plany i cele wydawnicze:

Rozpoczynając cykl pod nazwą: „Biblioteka Historyczna” i „Biblioteka Historyczno-Literacka", kierowało się wydawnictwo nasze tym przeświadczeniem, że dzieła w tych obu cyklach się ukazujące, nie będą przeznaczone tylko dla historyków i literatów, ale dla każdego kulturalnego czytelnika, który przez zgłębianie podstawowych prac historycznych i historyczno-literackich, będzie uzupełniał swą erudycję.

Podano nazwiska autorów i tytuły dzieł, które ukazały się w seriach „Czasy i Ludzie”, „Biblioteka Miniaturowa”, „Biblioteka Naukowa”, „Dla Dzieci i Młodzieży”. Nie pominięto również niezwykle ważnej serii zatytułowanej „Wielka Biblioteka”, w której drukowano arcydzieła literatury rodzimej i obcej. Wydawnictwo dbało o dobrą jakość publikowanych pozycji pod względem edytorskim, merytorycznym i dydaktycznym. W druku zaznaczono:

Nowe wydania „Wielkiej Biblioteki” przystosowane są do najnowszych postulatów nauczania literatury ojczystej i obcej. Na dział „objaśnień" składają się komentarze rzeczowe, językowe i historyczno-literackie, utrzymane w granicach takich, iż nie stoją na przeszkodzie samodzielnemu wysiłkowi myśli ucznia czy samouka [...]. Nowe wydania „Wielkiej biblioteki” [!] mogą budzić również szczególne zainteresowanie szerokiej publiczności, gdyż omówiony powyżej materiał „przypisów” jest niezmiernie interesujący sam w sobie, bezpośrednio i znakomicie wprowadza czytelnika w ducha epoki, przeżycia autora i dzieje utworu, a tym samym ułatwia należyte zrozumienie dzieła.

Z tej serii oferowano prace Juliusza Słowackiego, Sofoklesa, Leopolda Staffa, Władysława Syrokomli, Kazimierza Przerwy-Tetmajera, Stanisława Witkiewicza, Stanisława Wyspiańskiego i Franciszka Zabłockiego.

W katalogu Nowości Instytutu Wydawniczego Biblioteka Polska za rok 1935-6 na stronie pierwszej nieprzypadkowo zamieszczono fotografię Tadeusza Makowieckiego, autora Studium o Stanisławie Wyspiańskim (il. 3). W druku zawarto wiadomości, że książka ta ukazała się w serii „Biblioteka Pamiętnika Literackiego”, a ilustracje wykonano w rotograwiurze. Był to kolejny sukces wydawniczy: „Dzieło nagrodzone przez 


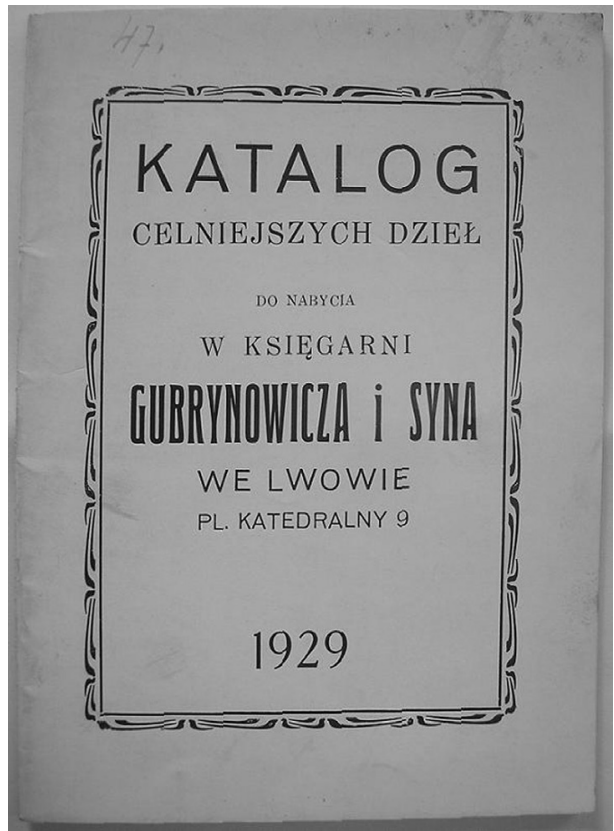

\section{Il. 2. Strona tytułowa katalogu lwowskiej} księgarni Gubrynowicza i Syna

Źródło: Wojewódzka i Miejska Biblioteka Publiczna w Bydgoszczy, Zb. Specj. Dżs. XVI. 2 -

Biblioteka Polska; fot. Ryszard Nowicki.

Il. 3. Strona tytułowa katalogu nowości wydawniczych Instytutu Wydawniczego „Biblioteka Polska” za lata 1935-1936 Źródło: Wojewódzka i Miejska Biblioteka Publiczna w Bydgoszczy, Zb. Specj. Dżs. XVI. 2 Biblioteka Polska; fot. Ryszard Nowicki.

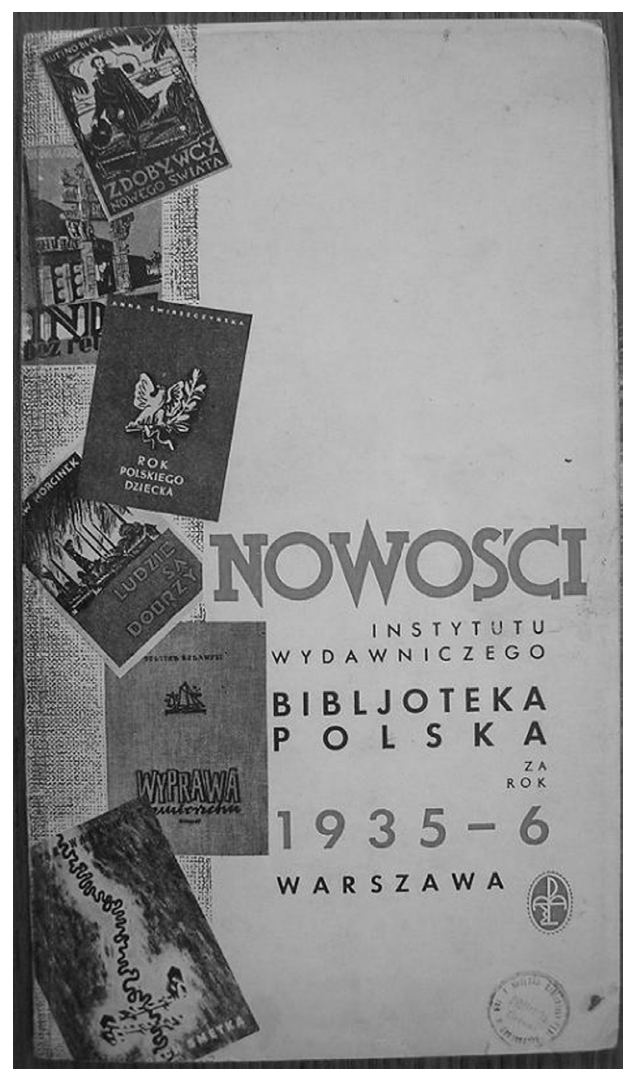


Polską Akademię Umiejętności jako najwybitniejsze z zakresu historii i historii literatury polskiej za rok 1935". W katalogu zasygnalizowano także przygotowywane nowe wydanie Fausta Johanna Goethego: „Arcydzieło genialnego autora $\mathrm{w}$ najlepszem kongenjalnem tłumaczeniu polskiem Władysława Kościelskiego".

W druku okolicznościowym zapowiadającym opublikowanie pracy Melchiora Wańkowicza Na tropach Smętka celowo powtórzono informację: „Istotnie, książka ta będzie rewelacyjna”. Na czwartej stronie natomiast przytoczono wybrane opinie na temat twórczości autora, w tym sądy Jana Bystronia, Konrada Górskiego, Karola Irzykowskiego, Juliana Kaden-Bandrowskiego, Jana Lenartowicza, Stefana Żeromskiego. Miały one dodatkowo zachęcić do nabycia dzieła.

Obok wielostronicowych druków okolicznościowych ukazywały się również jedno- lub dwustronne z informacją o nowościach wydawniczych. Przykładowo głosiły one: „Ozdobą każdej biblioteki są: [...]” lub „Biblioteka Polska S.A. poleca”. Pojawiały się także druki ulotne informujące o dziele jednego autora bądź o pracach zbiorowych. W ten sposób reklamowano m.in.: Dzieje literatury polskiej w zarysie Aleksandra Brücknera w dwóch tomach (il. 4) czy dwutomową Encyklopedię podręczna prawa publicznego pod redakcją Zygmunta Cybichowskiego. Wydawnictwo drukowało, jak wspomniano wcześniej, również czasopisma. Przykładem może być dwumiesięcznik "Polonista”, poświęcony sprawom nauczania języka polskiego. W druku ulotnym informowano o tym wydarzeniu i o planowanym terminie ukazania się pierwszego numeru (31 października $1930 \mathrm{roku}$ ).

W drukach ulotnych stosowano zróżnicowaną czcionkę, pismo proste, kursywę, pogrubienia, różnego rodzaju znaki typograficzne. Dbano o estetykę druku dostosowaną do formatu, przejrzysty układ i czytelność tekstu, odpowiednie światło pomiędzy literami. Chętnie wykorzystywano w ilustracjach motyw książki, który występował już na pierwszej stronie. Stosowano także odmienne rozwiązania typograficzne, jak w czterostronicowym druku okolicznościowym zachęcającym do nabycia książki Józefa Hoene-Wrońskiego Filozofia matematyki (il. 5). Pierwsza strona pozbawiona jest jakiejkolwiek ilustracji. Jedynie w dolnej części zamieszczono napis: „Ukazało się w druku dzieło, od dawna oczekiwane w Polsce”. Uwagę czytelnika przyciąga czerwona litera U. Aby dowiedzieć się, jakiego dzieła dotyczy, koniecznie trzeba wziąć do ręki druk i spojrzeć na następne strony. 


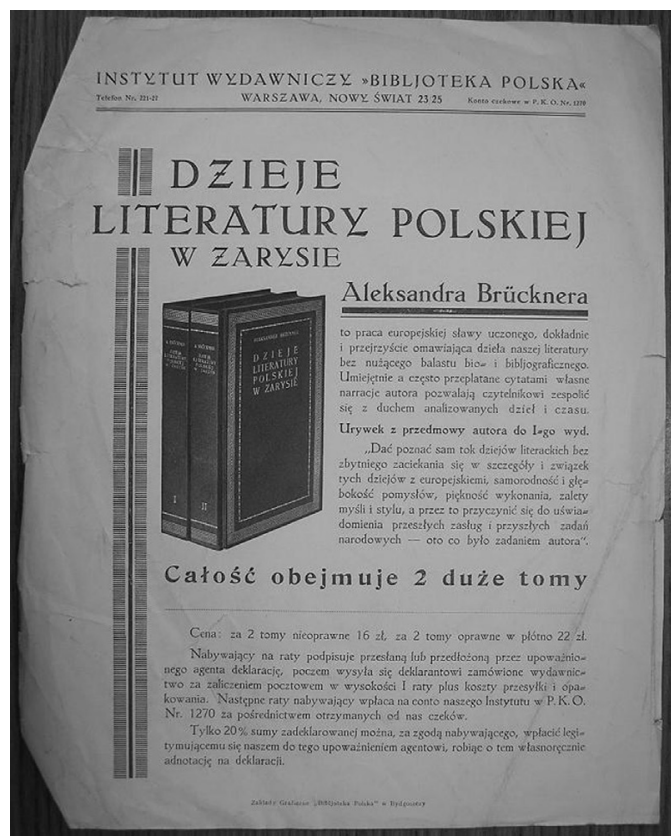

Il. 4. Druk reklamujący Dzieje literatury polskiej w zarysie Aleksandra Brücknera

Źródło: Wojewódzka i Miejska Biblioteka Publiczna w Bydgoszczy, Zb. Specj. Dżs. XVI. 2 - Biblioteka Polska; fot. Ryszard Nowicki.

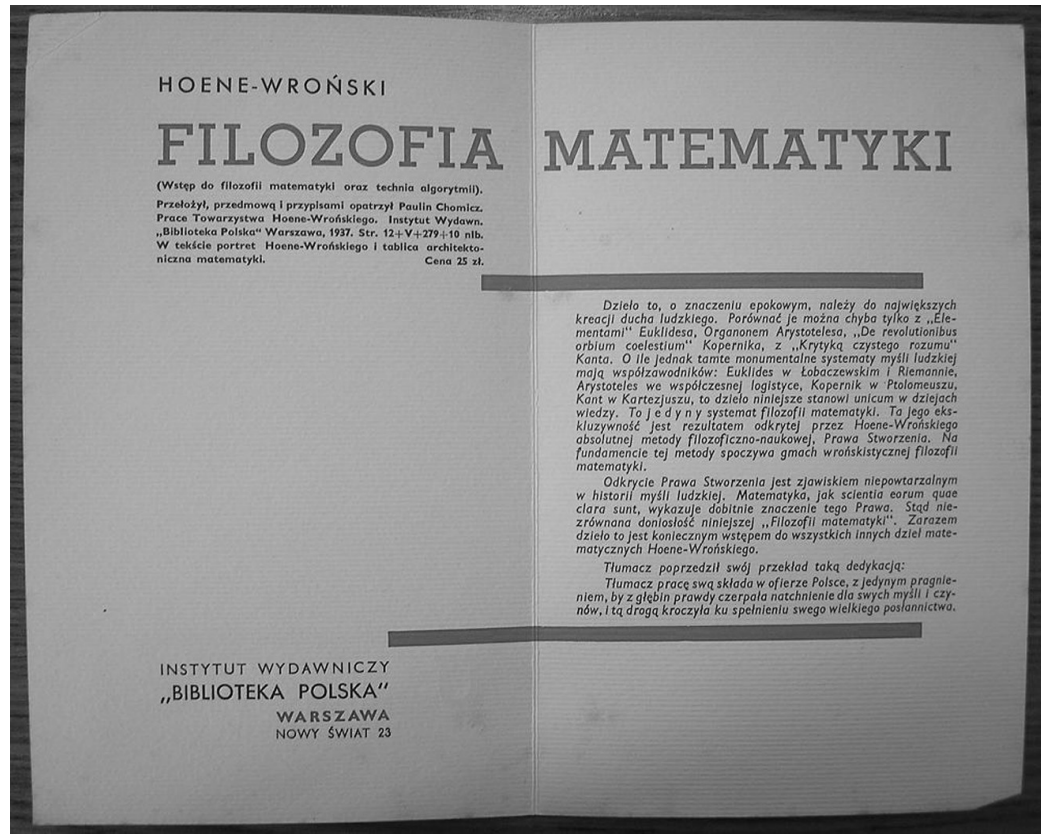

Il. 5. Przykład nowoczesnego układu graficznego zastosowanego w reklamie książki Józefa Hoene-Wrońskiego Filozofia matematyki

Źródło: Wojewódzka i Miejska Biblioteka Publiczna w Bydgoszczy, Zb. Specj. Dżs. XVI. 2 - Biblioteka Polska; fot. Ryszard Nowicki. 
Pojawiały się druki ulotne w formie zakładek do książek. Na jednej z nich przedstawiono ilustrację osoby czytającej w pozycji leżącej. Druga strona zawiera reklamę popularnej serii:

„Wielka Biblioteka” nowe wydanie arcydzieł literatury polskiej i obcej w opracowaniu pedagogów i krytyków. Dotychczas wyszły z druku dzieła Krasińskiego, Mickiewicza, Wyspiańskiego, Słowackiego, Kochanowskiego, Krasickiego, Fredry, Niemcewicza, Moliera, Szekspira, Malczewskiego, Asnyka, Waltera Scot[t]a, Paska, Szajnochy, Byrona, Potockiego, Sienkiewicza, Żeromskiego.

Można zidentyfikować autorów druków ulotnych. Wydawnictwo współpracowało z artystami oraz realizowało projekty uznanych grafików i ilustratorów książek. Byli wśród nich m.in.: Zygmunt Anczykowski, Stanisław Bobiński czy Adam Bowbelski, związany z założonym w Warszawie w 1933 roku Kołem Artystów Grafików Reklamowych, które dążyło do podniesienia poziomu grafiki użytkowej w Polsce. Warto wspomnieć, że członkiem koła był Adam Półtawski, twórca pierwszej polskiej czcionki - antykwy Półtawskiego. Z wydawnictwem związani byli ilustratorzy Janina Petry-Przybylska i Stefan Norblin oraz plakaciści Andrzej Stępiński i Jerzy Skolimowski. Stanisław Brzęczkowski zawodowo zajmował się grafiką wydawniczą i ilustracją książkową dla Zakładów Graficznych. Był on autorem licznych afiszy, kalendarzy, plakatów i innych druków okolicznościowych Instytutu Wydawniczego. Jego autolitograficzna Teka miast pomorskich, wydana w nakładzie 300 egzemplarzy, została odnotowana w katalogu Nowości Instytutu Wydawniczego Biblioteka Polska za rok 1935-6.

Druki ulotne wykonywano również na zamówienie innych wydawnictw, np. warszawskiego Wydawnictwa Gutenberga. Zapowiadano w ten sposób mające się ukazać powieści Karola Dickensa (il. 6). W druku zawarto podobiznę autora, zwięzłe wiadomości o dziełach, rysunek jednego tomu w skali 1:1, przykładowe ilustracje z wybranych powieści oraz widok 12 tomów z informacją iż pozycje te "tworzą piękną bibliotekę domową".

Instytut Wydawniczy posiadał własną księgarnię sortymentową w Warszawie, przy Nowym Świecie, założoną w 1924 roku. Należała ona do najnowocześniejszych i największych w kraju. Została uznana, ze względu na estetykę wnętrza, za najpiękniejszą w Polsce. Placówką kierował Aleksander Kołłupajło. Liczne druki ulotne dostarczają wiedzy o tej jedynej księgarni wydawnictwa (il. 7, 8). Przykładowo podstawowe wiadomości o niej zawarto na kalendarzykach z 1935 roku z wizerunkami młodej damy trzymającej książkę. Z podanych informacji wynika, że księgarnia posiadała na składzie bogaty asortyment dzieł wydanych 


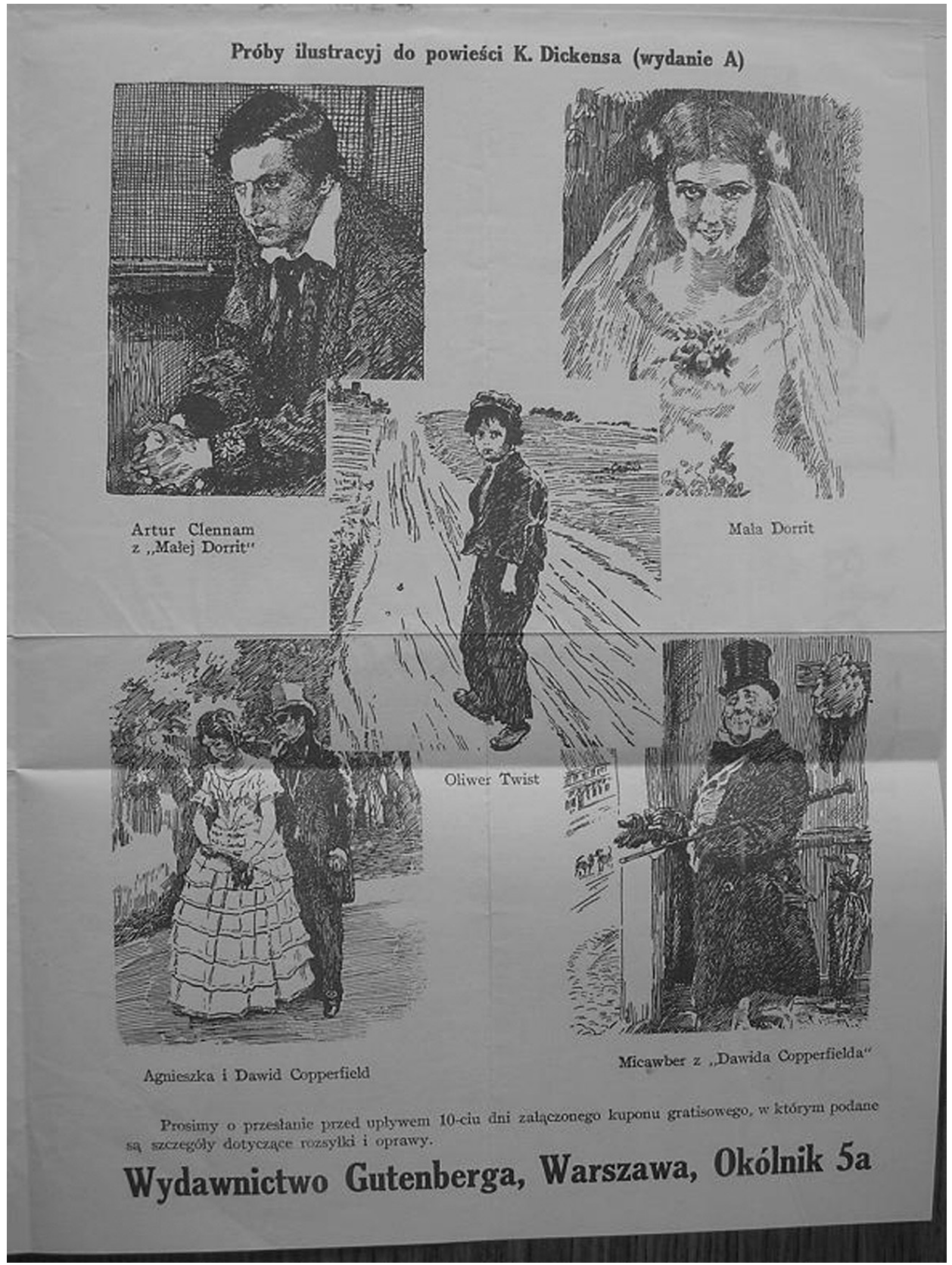

Il. 6. Druk zapowiadający wydanie dzieł Karola Dickensa

Źródło: Wojewódzka i Miejska Biblioteka Publiczna w Bydgoszczy, Zb. Specj. Dżs. XVI. 2 Biblioteka Polska; fot. Ryszard Nowicki. 


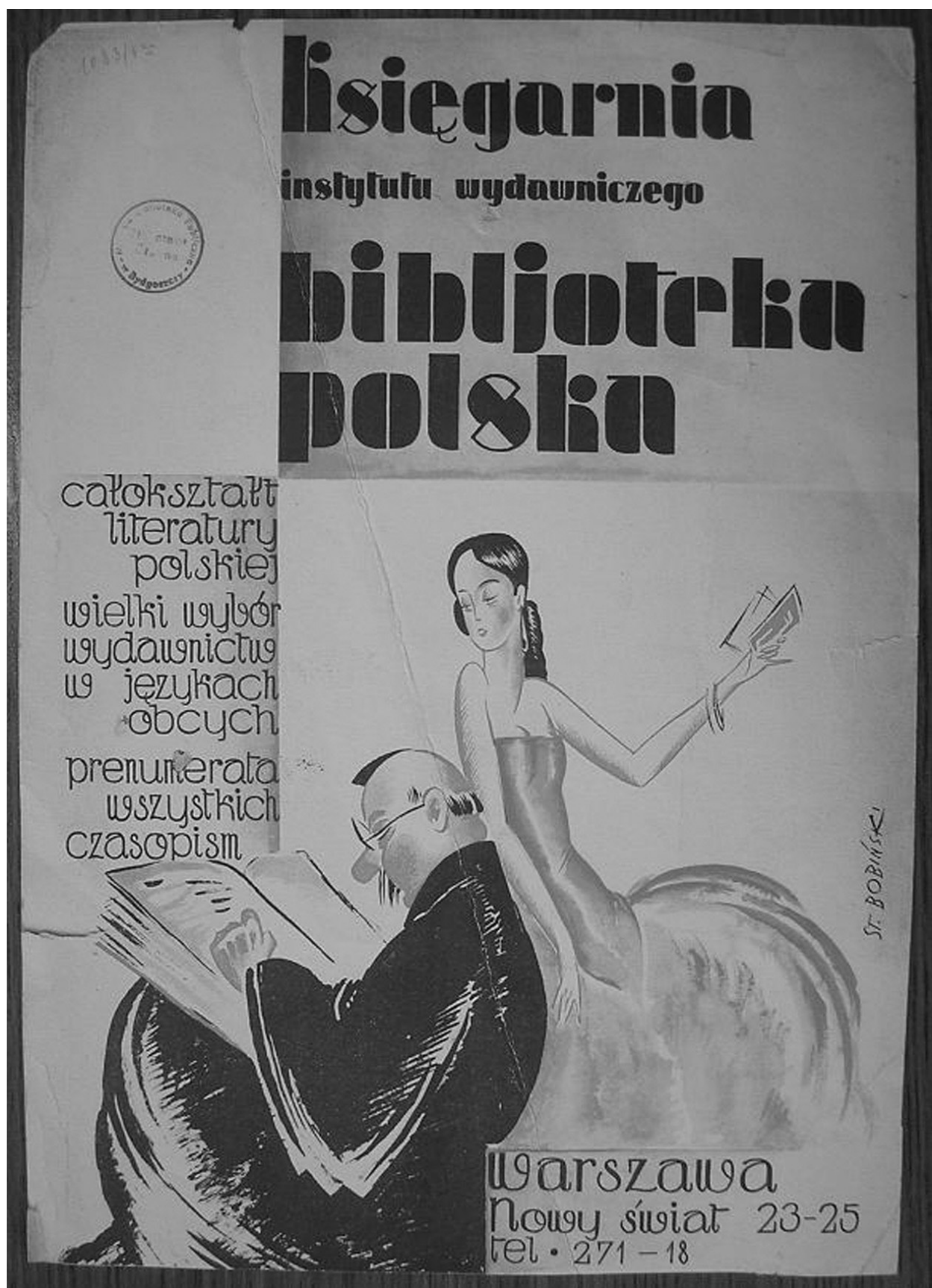

Il. 7. Druk reklamujący księgarnię Instytutu Wydawniczego „Biblioteka Polska” w Warszawie

Źródło: Wojewódzka i Miejska Biblioteka Publiczna w Bydgoszczy, Zb. Specj. Dżs. XVI. 2 Biblioteka Polska; fot. Ryszard Nowicki. 


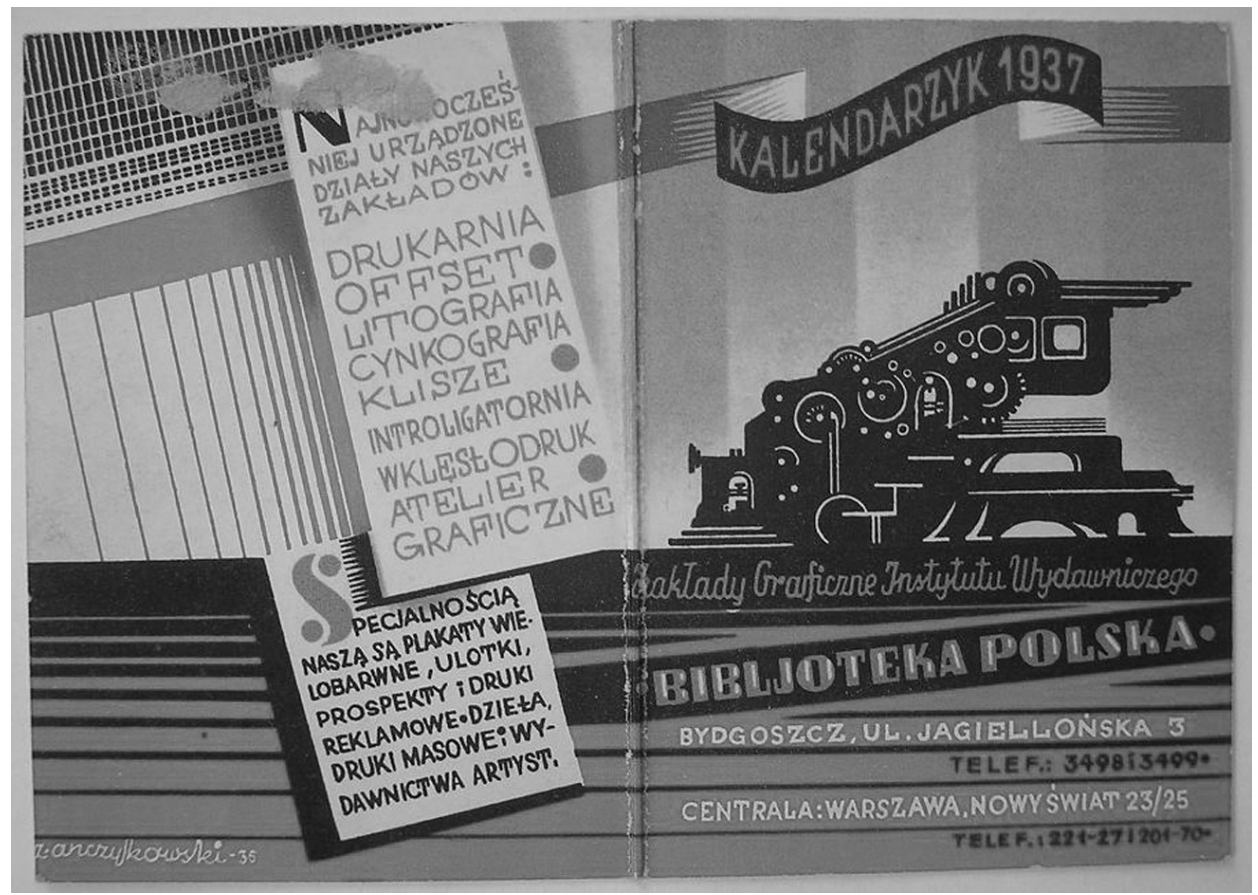

Il. 8. Kalendarzyk Zakładów Graficznych Instytutu Wydawniczego „Biblioteka Polska" na rok 1937

Źródło: Wojewódzka i Miejska Biblioteka Publiczna w Bydgoszczy, Zb. Specj. Dżs. XVI. 2 Biblioteka Polska; fot. Ryszard Nowicki.

$\mathrm{w}$ językach polskim, angielskim, francuskim, niemieckim, rosyjskim oraz włoskim, otrzymywała nowości w językach polskim i obcych, prowadziła sprzedaż czasopism krajowych, a także zagranicznych, przyjmowała prenumeratę na dzienniki polskie i zagraniczne, realizowała wszelkie zlecenia z zakresu księgarstwa. W innych drukach zachęcano do odwiedzenia księgarni, która posiadała „całokształt literatury polskiej[,] wielki wybór wydawnictw w językach obcych". Informowano o hurtowej ekspedycji wydawnictw własnych, bezpłatnym wysyłaniu katalogów księgarskich, olbrzymim asortymencie dzieł krajowych i zagranicznych oraz podręczników szkolnych. Trzeba przyznać, że księgarnia była znakomicie zaopatrzona i stanowiła swego rodzaju wizytówkę Instytutu Wydawniczego oraz Zakładów Graficznych.

Wiele druków ulotnych dotyczy samych Zakładów Graficznych Instytutu Wydawniczego „Biblioteka Polska” (il. 9). Zamieszczone zostały w nich informacje o działach bydgoskich zakładów, maszynach drukarskich, pracownikach. Pojawiają się także dane o roku założenia drukarni (1806) oraz rysunki Zakładów Graficznych. Jak wcześniej wspomniałem, 
zakłady powstały w 1920 roku. Zamieszczona natomiast data z początku XIX wieku odwołuje się do pierwszej bydgoskiej drukarni założonej przez Niemca Andreasa Grünauera. Jego warsztat, początkowo skromny, z czasem znacznie się rozrósł. W 1919 roku został zakupiony przez Władysława Kościelskiego. Podkreślono w ten sposób ciagłość tradycji drukarskich w Bydgoszczy.

Cenne są wizerunki, już nieistniejących, Zakładów Graficznych utrwalone w drukach okolicznościowych. Tam, gdzie niegdyś funkcjonowały, stoi galeria handlowa. I tylko jej nazwa, „Drukarnia”, nawiązuje do historycznego miejsca działalności tej jakże ważnej dla Bydgoszczy, regionu i kraju instytucji kultury książki. Uwieczniony został realistyczny rzut z góry budynków. Przedstawiano je także w uproszczonej formie, za pomocą schematycznego rysunku. Dają one pogląd co do wielkości zakładów. Kilka obiektów z zaznaczonymi kondygnacjami tworzyło prostokąt z wewnętrznym dziedzińcem. Nad bramą wjazdową widniała nazwa zakładów, którą powtórzono na najwyższym kilkupiętrowym budynku.

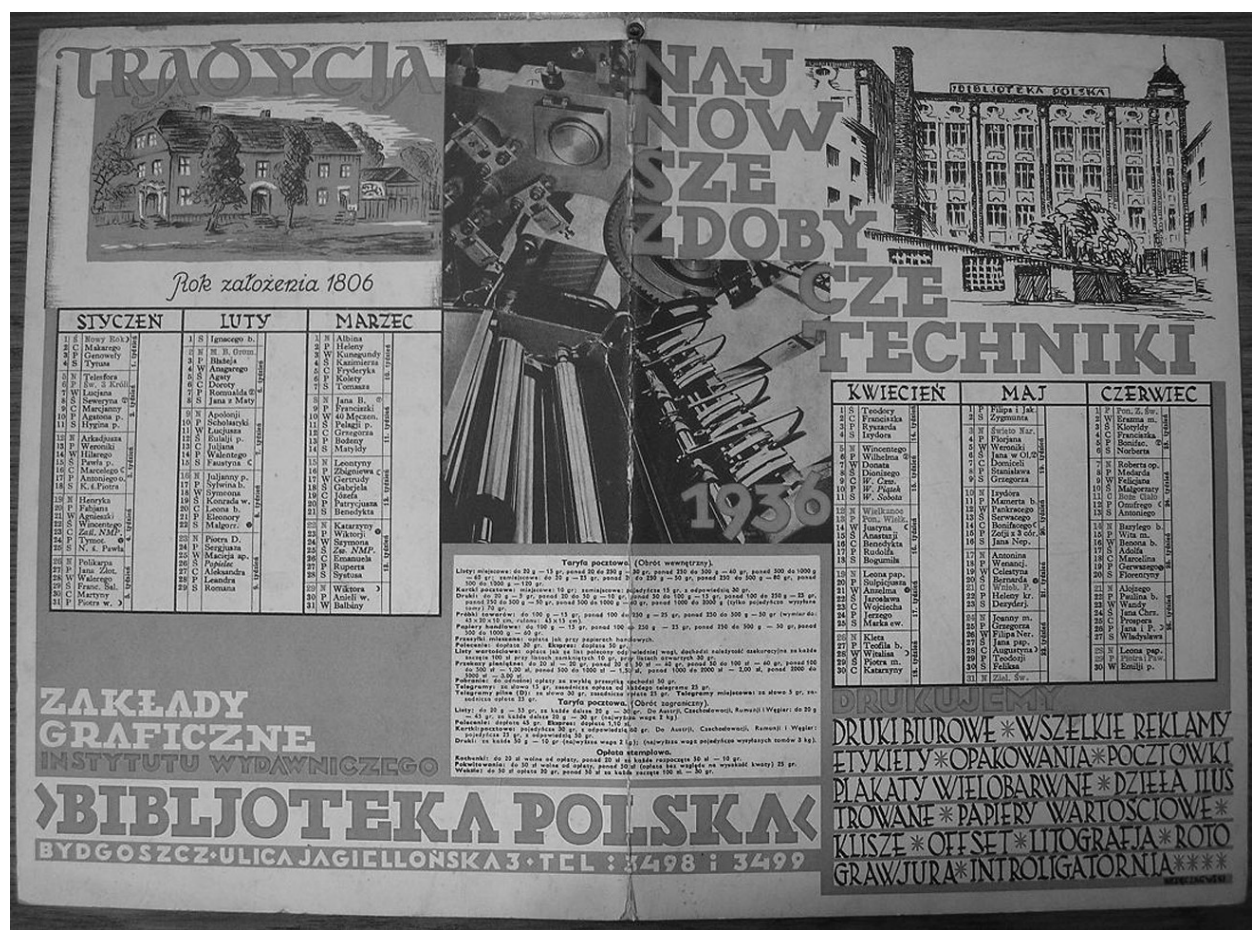

Il. 9. Kalendarz na rok 1936

Źródło: Wojewódzka i Miejska Biblioteka Publiczna w Bydgoszczy, Zb. Specj. Dżs. XVI. 2 Biblioteka Polska; fot. Ryszard Nowicki. 
W kalendarzach widoki zakładów były niejednokrotnie dodatkowo wzbogacone ilustracjami pracowników, którzy wykonywali swoje codzienne czynności zawodowe - zarówno mężczyzn, jak i kobiet. Widzimy ich przy maszynach rotacyjnych, dostrzegamy linotypistów, korektora, grafika, litografa, malarza, fotografa i innych. Przedstawiono wnętrza z maszynami drukarskimi podczas procesu produkcyjnego. Jest to autentyczny, realistyczny wygląd zakładów i pracujących w nich ludzi (il. 10, 11) .

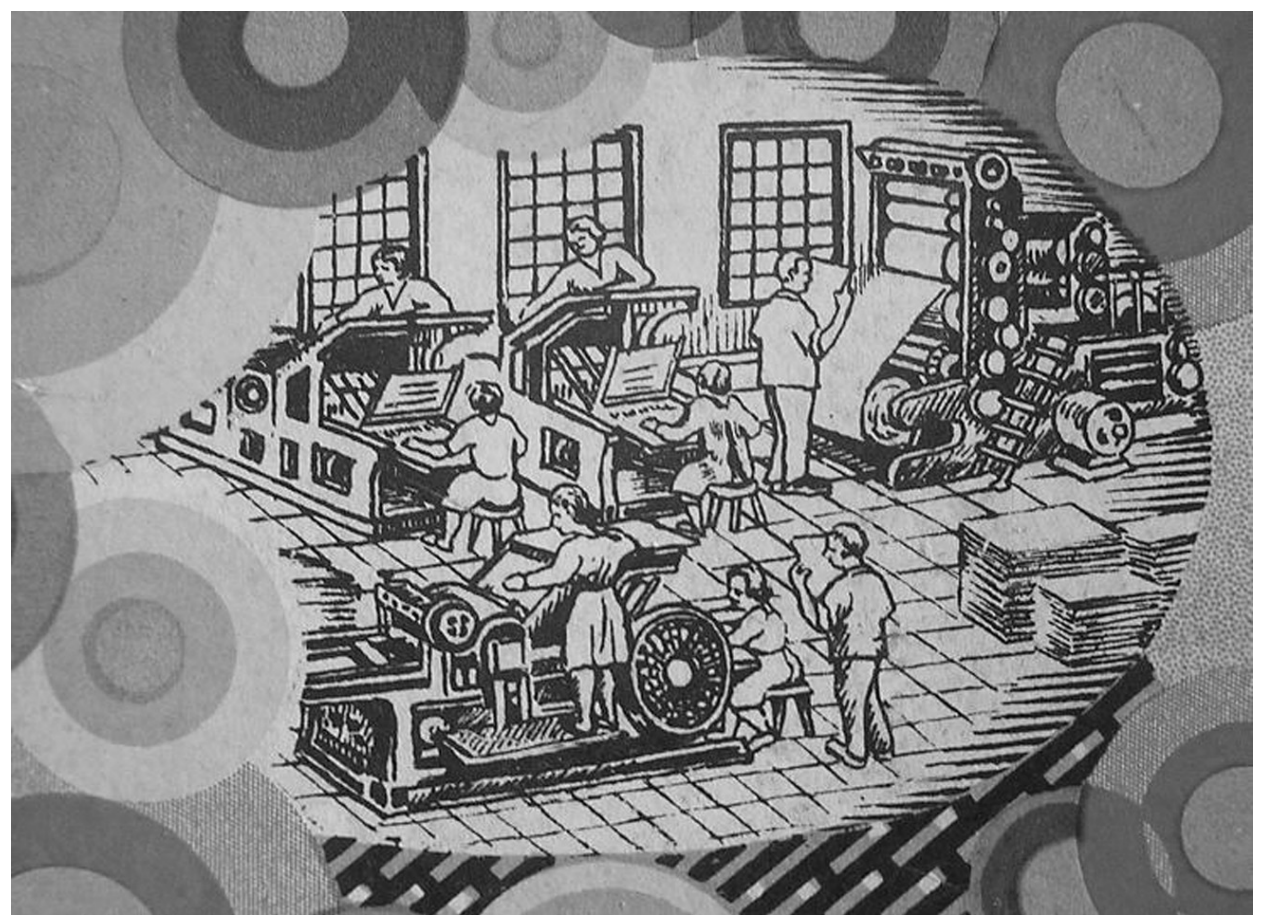

Il. 10. Wnętrze drukarni (fragment kalendarza na rok 1931)

Źródło: Wojewódzka i Miejska Biblioteka Publiczna w Bydgoszczy, Zb. Specj. Dżs. XVI. 2 Biblioteka Polska; fot. Ryszard Nowicki.

Druki ulotne dostarczają wiedzy na temat postępującej modernizacji drukarni. Z dumą informowano o zakupie nowoczesnych maszyn do zmechanizowanego składu tekstów, wykorzystywanych do druku wydawnictw seryjnych oraz wydawnictw artystycznych. Pracowały maszyny

${ }^{9}$ Zob. R. Nowicki, Bydgoszcz jako miasto kultury ksią̇ki, w: Studia z dziejów książki i prasy. Przeglad badań za lata 2007-2010, red. Z. Kropidłowski, D. Spychała, K. Wodniak, Bydgoszcz 2010, s. 103. 


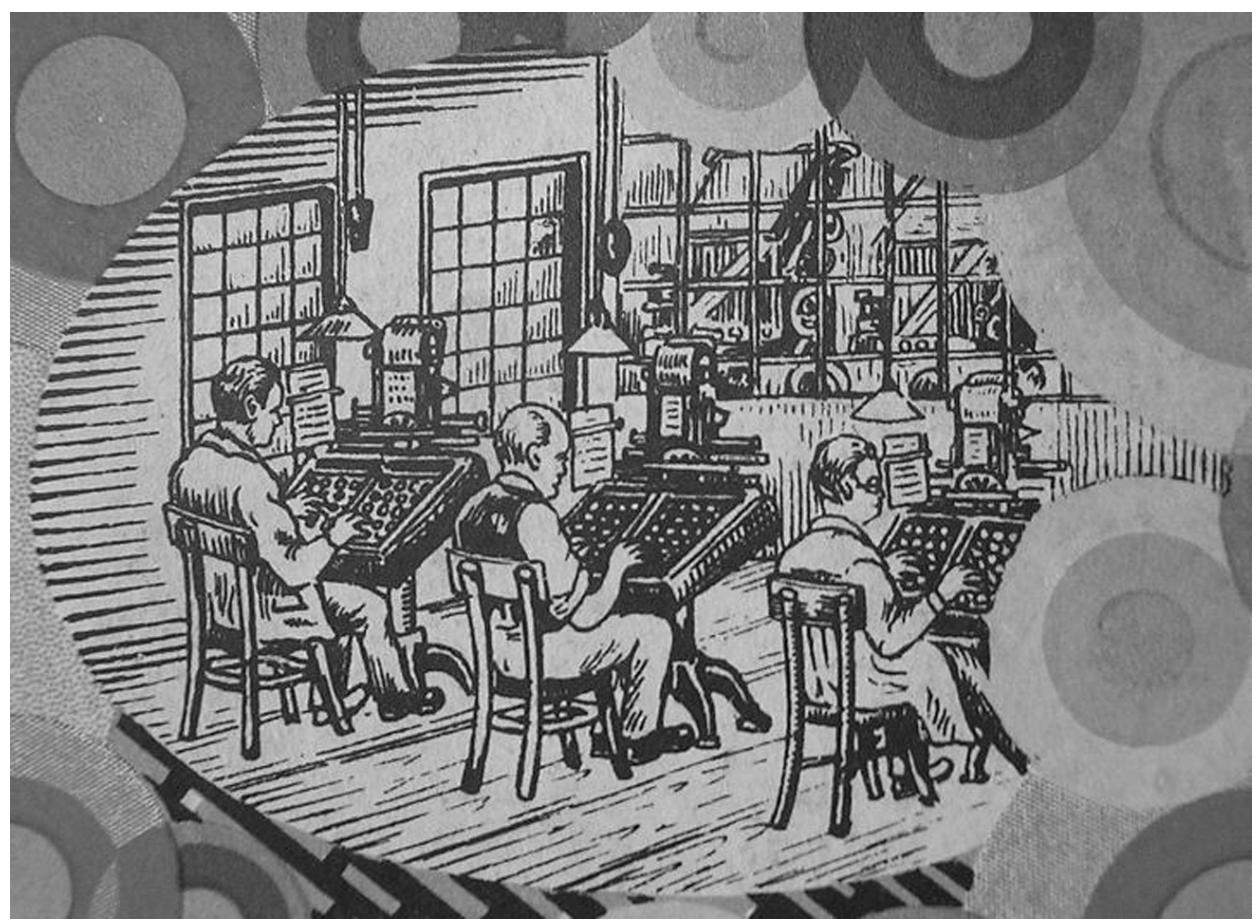

Il. 11. Linotypiści przy pracy (fragment kalendarza na rok 1931)

Źródło: Wojewódzka i Miejska Biblioteka Publiczna w Bydgoszczy, Zb. Specj. Dżs. XVI. 2 Biblioteka Polska; fot. Ryszard Nowicki.

monotypowe i linotypowe, ale stosowano również skład tradycyjny, znany od stuleci - ręczny. Przykładem może być dwustronny kalendarz na rok 1932. Jedna z ilustracji przedstawia bowiem zecera stojącego przed kasztą z czcionkami.

W kalendarzu z 1935 roku w formie graficznej nawiązano do postępujących zmian $w$ procesie wydawania książek (il. 12). Ukazuje on swego rodzaju zjawę nadnaturalnej wysokości, drukarza pracującego przy drukarni ręcznej. Być może wizerunek ów symbolizuje samego Jana Gutenberga. Poniżej dostrzegamy współczesnego pracownika obsługującego maszynę rotacyjną. Nawiązano świadomie do przeszłości, w ikonograficzny sposób wyrażono szacunek do tradycji typograficznych.

Z kalendarza na rok 1937 wynika, że jest to największa w Polsce drukarnia, a „najnowsze urządzenia zakładów pozwalają na szybkie i pierwszorzędne wykonanie dzieł sztuki, plakatów, reklam, ilustracji, opakowań, etykiet, pocztówek, klisz jedno i wielobarwnych" (il. 13). Do poprawy jakości druków przyczynił się m.in. zakup nowoczesnych maszyn offsetowych. 


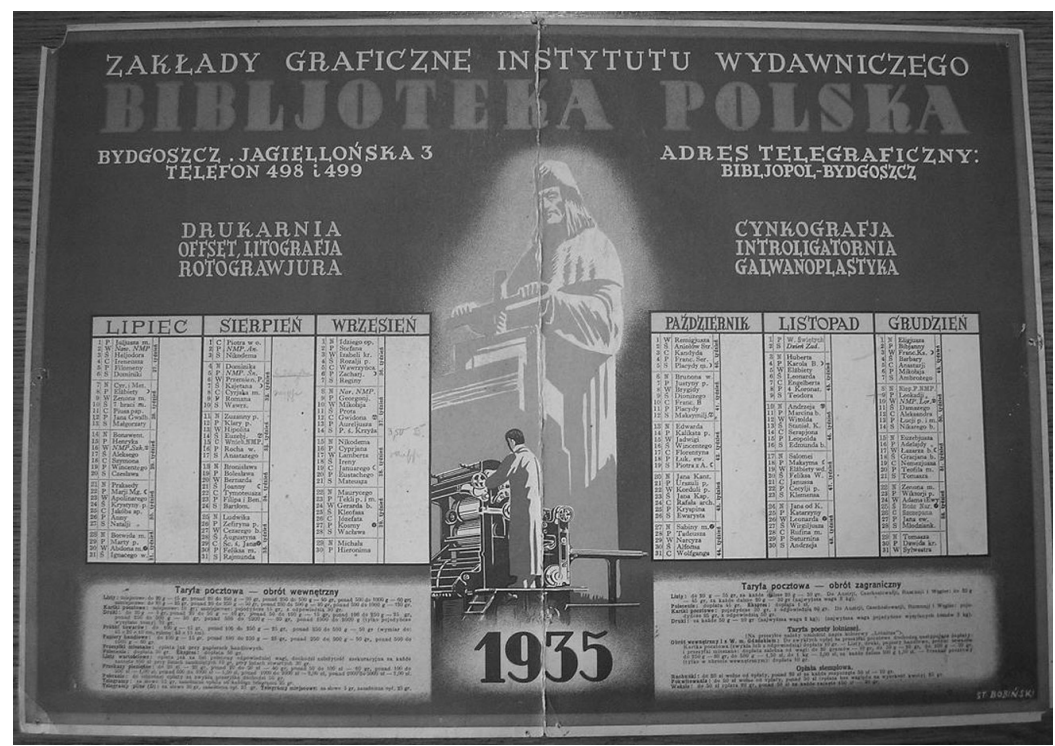

Il. 12. Kalendarz na rok 1935

Źródło: Wojewódzka i Miejska Biblioteka Publiczna w Bydgoszczy, Zb. Specj. Dżs. XVI. 2 - Biblioteka Polska; fot. Ryszard Nowicki.

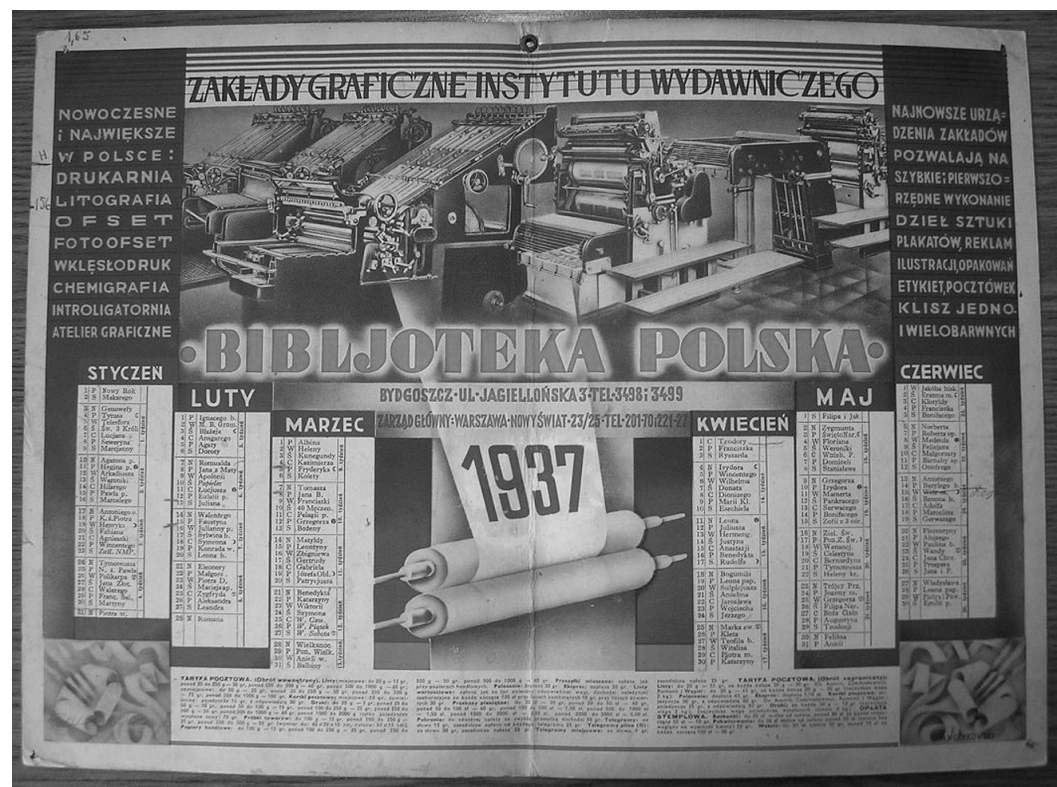

Il. 13. Kalendarz na rok 1937

Źródło: Wojewódzka i Miejska Biblioteka Publiczna w Bydgoszczy, Zb. Specj. Dżs. XVI. 2 - Biblioteka Polska; fot. Ryszard Nowicki. 
W kalendarzu na rok 1939 można dostrzec fragmenty plakatów wydanych przez Zakłady Graficzne. W innym kalendarzu, opublikowanym także na ten rok, napis „Biblioteka Polska” został złożony z czcionek przedstawionych $\mathrm{w}$ formie graficznej.

Interesujący, o walorach bibliofilskich, jest druk okolicznościowy wydany z okazji „Wieczornicy Gwiazdkowej”, organizowanej przez Związek Drukarzy Polskich Okręg Bydgoszcz (il. 14). W opracowanym z dużą

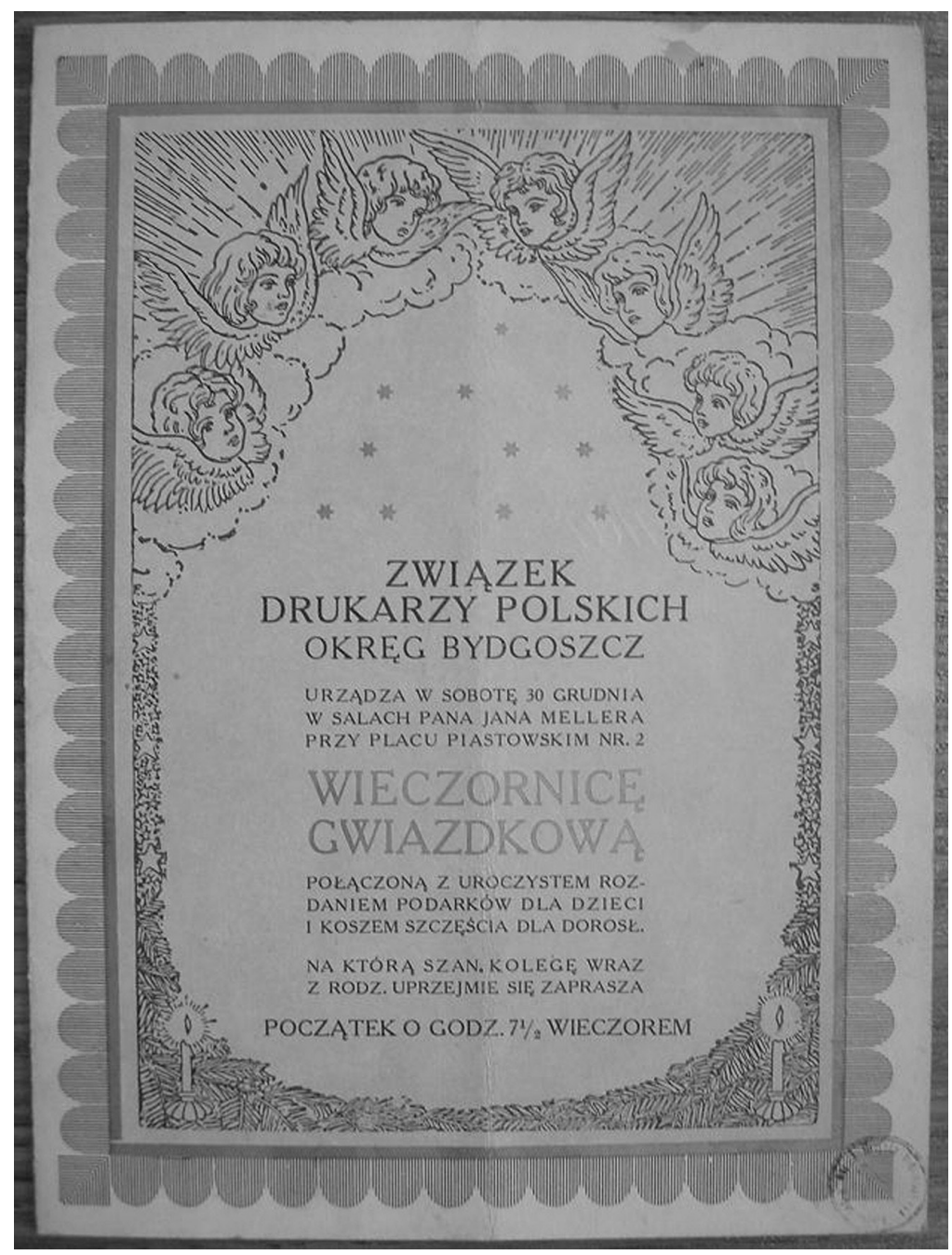

Il. 14. Strona tytułowa zaproszenia na „Wieczornicę Gwiazdkową” Związku Drukarzy Polskich Okręg Bydgoszcz

Źródło: Wojewódzka i Miejska Biblioteka Publiczna w Bydgoszczy, Zb. Specj. Dżs. XVI. 2 - Biblioteka Polska; fot. Ryszard Nowicki. 
starannością typograficzną materiale odnotowano fakt istnienia w Bydgoszczy związku, do którego należeli również pracownicy Zakładów Graficznych Instytutu Wydawniczego. Stanowi on dowód na organizowanie imprez towarzyskich, a także dostarcza dodatkowej wiedzy na temat kulturalnego spędzania wolnego czasu. W punkcie trzecim programu utrwalono nazwę chóru „Typografia”. Okres dwudziestolecia międzywojennego w Polsce obfitował w działalność wielu amatorskich zespołów śpiewaczych. Istniały i prężnie działały również w mieście nad Brdą.

$Z$ zaledwie zasygnalizowanych wybranych przykładów wynika, że druki ulotne i okolicznościowe Zakładów Graficznych Instytutu Wydawniczego „Biblioteka Polska”:

- stanowią niezwykle interesujący materiał źródłowy o charakterze dokumentacyjnym, historycznym i estetycznym,

- zawierają cenne informacje o przeszłości Instytutu Wydawniczego „Biblioteka Polska”,

- dostarczają wiadomości o rozwoju firmy, liczbie pracowników, postępującej modernizacji Zakładów Graficznych,

- posiadają niejednokrotnie wysoką wartość estetyczna, o którą zadbali cenieni artyści - graficy i ilustratorzy książek,

- zawierają ikonografię, która utrwaliła wygląd zewnętrzny i wewnętrzny obiektów, pracowników wykonujących czynności zawodowe, maszyny drukarskie,

- kierowane były do szerokiego kręgu odbiorców, cechowała je komunikatywność i czytelność,

- pełniły przede wszystkim funkcję informacyjno-reklamowa,

- wprowadzone do obiegu czytelniczego wykazują zróżnicowanie pod względem treści i formy typograficznej (ze względu na charakter zdobnictwa, układ graficzny czy dobór czcionek),

- stanowią dowód kulturotwórczej działalności Instytutu Wydawniczego „Biblioteka Polska” i pochwały książki,

- odegrały istotną rolę w kształtowaniu świadomego odbiorcy książki i prasy,

- dowodza, iż Bydgoszcz po raz pierwszy stała się znaczącym ośrodkiem kultury książki w skali kraju,

- stanowią pomocne źródło przy odtwarzaniu repertuaru wydawniczego i nie sposób ich pominąć w przyszłych badaniach, prowadzących do powstania pełnej monografii naukowej dotyczącej działalności Instytutu Wydawniczego oraz bydgoskich Zakładów Graficznych. 


\title{
Commemorative brochures and notelets published by Zakłady Graficzne Instytutu Wydawniczego "Biblioteka Polska" in the collection of the Provincial and Municipal Public Library in Bydgoszcz. A contribution to the history of the publisher
}

\begin{abstract}
Aвstract. Zakłady Graficzne Instytutu Wydawniczego "Biblioteka Polska" (Biblioteka Polska Publishing House) operated in Bydgoszcz between 1920-1939. The printing office was established by Władysław Kościelski, a member of the Wielkopolska landed gentry. It was one of the biggest and the most technically advanced publishing house in Poland of the inter-war period. "Biblioteka Polska", with its seat in Warsaw, published works of several hundred Polish and foreign authors in publishing series. It publishing output was complemented with numerous commemorative brochures, leaflets and notelets issued along with the printed publications. This group of publications, addressed to a wide circle of receivers, was characterised by straightforwardness in the expression and legibility. Basically, they were to convey information or were issued for commercial or marketing purposes. They show a remarkable variation in terms of their content and topographical form (as regards the nature of ornamentation, graphical layout or typesetting). These leaflets had their share in the formation of the proper receiver of the book and the press, contributed to the formation of readership and the reader's needs, and to promotion of literary and scientific output of writers and scholars. They were designed by renown graphic designers, including book illustrators. In all, they constitute valuable source material of documental, historical and aesthetic nature.
\end{abstract}

Key words: Instytut Wydawniczy "Biblioteka Polska” (Warszawa), ZGIW "Biblioteka Polska" (Bydgoszcz), Władysław Kościelski, commemorative brochures and leaflets, printing industry, editorship, bookselling, Provincial and Municipal Library in Bydgoszcz, library collections. 
